\title{
SULAP SAMPAH JADI RUPIAH
}

\author{
Erlin \\ Program Studi Pendidikan Guru Sekolah Dasar \\ Fakultas Keguruan dan Ilmu Pendidikan \\ Universitas Nahdlatul Ulama Sidoarjo \\ Email: erlin10501@gmail.com
}

\section{Pengantar}

Sampah adalah suatu barang atau bahan yang dihasilkan dari aktivitas makhluk hidup yang dibuang karena sudah tidak layak dipakai atau sudah tidak memiliki nilai. Memang manusia tidak terlepas dari yang namanya sampah. Sampah menumpuk dimana-mana. Tempat berkumpulnya banyak orang dapat menjadi penghasil sampah seperti pasar, rumah tangga, industri dan perkantoran.

Sampah ada dua macam, yaitu sampah organik dan sampah anorganik. Sampah organik adalah sampah yang berasal dari makhluk hidup seperti: tumbuhan dan hewan. Sampah organik ini tidak bermasalah karena mudah terurai oleh bakteri tanpa perlu tambahan atau bantuan dari bahan kimia didalamnya. Sehingga bisa menyatu kembali dengan alam. Biasanya sampah organik ini diolah menjadi pupuk organik.

Sedangkan sampah anorganik adalah sampah yang dihasilkan dari berbagai macam proses dengan bantuan tangan manusia seperti: kaleng, kertas, botol, plastik dan lain-lainnya. Sampah anorganik sulit terurai oleh bakteri dan penguraiannya membutuhkan waktu yang sangat lama. Sehingga sampah anorganik ini menjadi berpengaruh terhadap lingkungan seperti pencemaran lingkungan.

Namun jika kita mengolah sampah anorganik menjadi sebuah barang yang antik dan apalagi menjual hasil pengolahan sampah kita besar kemungkinan hasilnya akan memuaskan kita.

Mengapa memilih sampah?. Kata-kata ini sering dipertanyakan oleh masyarakat. Mereka menilai kalau sampah itu hanya sebuah barang bekas yang tidak ada harganya. Padahal disisi lain, jika kita bisa mengolahnya dengan baik maka sampah ini bisa disulap menjadi rupiah. Jika kita memanfaatkan banyak sampah, kita sudah membantu mengurangi polusi atau pencemaran di sekitar kita. Dengan bermodalkan kreativitas serta menjadikan sampah sebagai bahan utamanya, maka kita bisa jadikan sampah ini menjadi barang yang bernilai cukup tinggi. 


\section{Lingkungan}

Minimnya kepedulian masyarakat ini menjadi faktor utama lingkungan tercemar, seperti udara yang tercemar karena asap kendaraan, sungai yang tercemar karena limbah dari aktivitas pabrik-pabrik besar, dan juga tanah yang tercemar karena adanya sampah.

Adanya sampah ini juga termasuk minimnya kepedulian masyarakat. Mereka tidak perduli dengan lingkungan sekitar mereka. Mereka tidak memikirkan bagaimana dampak kedepannya jika terusmenerus membuang sampah sembarangan.

Jadi jangan heran jika tiba-tiba banjir melanda. Faktor utama terjadi banjir itu karena menumpuknya sampah yang ada disungai. Sampahsampah tersebut ada karena masyarakat yang membuang sampah sembarangan. Apalagi membuang sampahnya di sungai. Sampahsampah yang ada disungai bisa mengakibatkan ikan-ikan kecil mati, dan juga air bisa menjadi keruh. Bau sampah disungai itu karena minimnya oksigen, jadi tak heran saat kita melintas di sekitar sungai yang terdapat sampah baunya sangat menyengat.

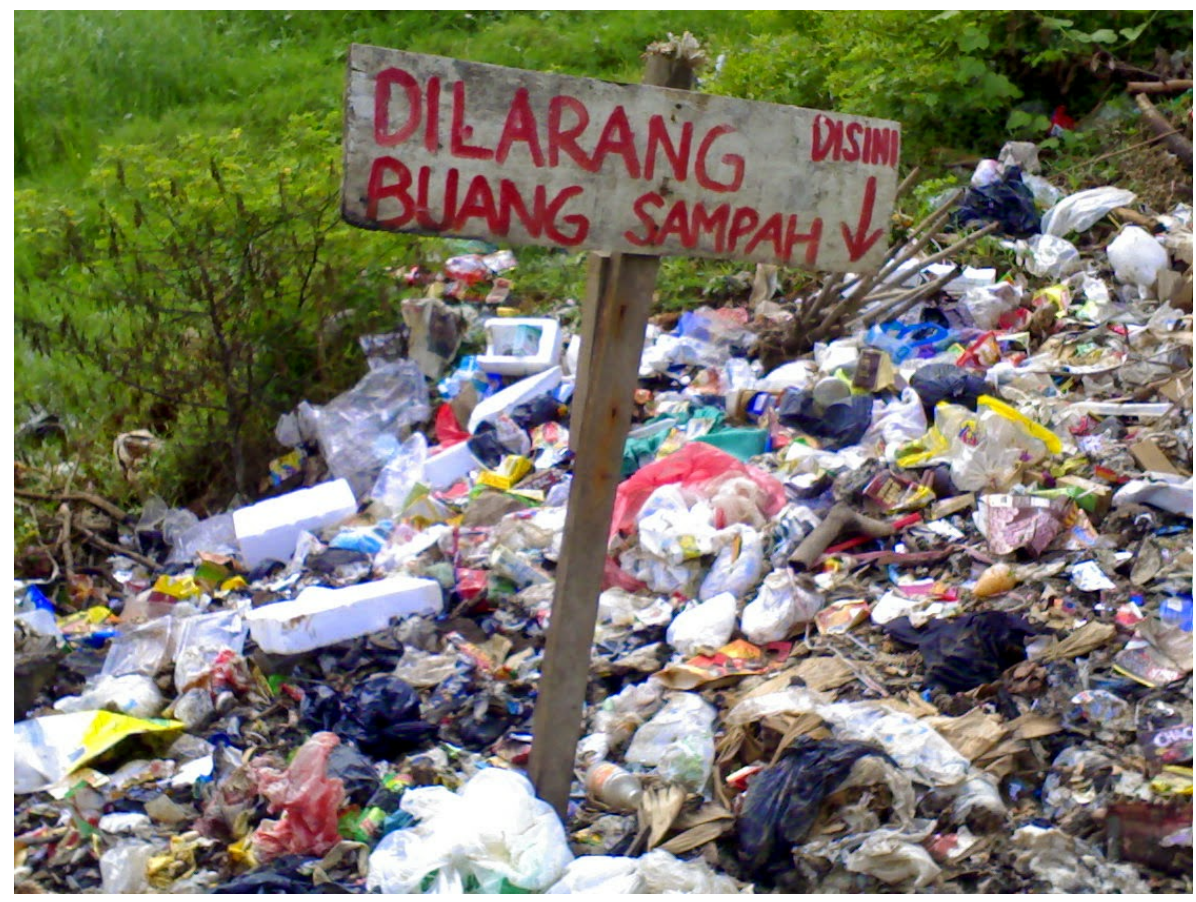

Gambar 1. Pengertian, Jenis dan Dampak Sampah (KajianPustaka.com)

Lalu Bagaimana kita bisa menumbuhkan kepedulian masyarakat kembali? Dengan cara memberikan mereka pengetahuan akan tentang bahaya membuang sampah sembarangan, mengadakan GPL (Gerakan Peduli Lingkungan) yang diadakan setiap hari minggunya. Bagi bapakbapak membersihkan sampah disekitar rumah, jalan, dan lain sebagainya. 
Dan ibu-ibu ditugaskan untuk memilah sampah kering dan sampah basah. agar mudah memilih sampah, disetiap rumah sebaiknya disiapkan dua tempat sampah yang satu untuk sampah kering dan satu lagi untuk sampah basah.

\section{Perekonomian Indonesia}

Rendahnya Kurs mata uang ini menjadi pemicu utama perekonomian di Indonesia saat ini. (Purnomo,H 2018) memberitakan bahwa Dolar AS terhadap rupiah telah menembus rekor baru pada hari ini, Jumat (29/6/2018). Rupiah memang mencatatkan pelemahan terhadap dolar AS dan menembus level di atas Rp 14.000 sejak 8 Mei 2018. Bahkan pada hari ini (29/6/2018) berdasarkan kurs acuan JISDOR Bank Indonesia, rupiah terhadap dolar mencatatkan rekor terburuknya di level Rp 14.404 per dolar AS. Nilai terkuat rupiah sejak awal 2018 ini terjadi pada 25 Januari 2018, yang mencapai Rp 13.290. namun nilai rupiah terhadap dolar terus melemah dan tak jauh dari level Rp 13.500-Rp 14.000 per dolar AS. Nilai rupiah jika ditarik kebelakang, pada 2014 dolar AS masih berada di Rp 11.200 pada april 2018. Kemudian dolar AS terus menguat melawan rupiah hingga menyentuh Rp 14.700 pada oktober 2015. Saat ini dolar kembali menguat dan mencatatkan level tertingginya di Rp 14.400. Seperti ini gambaran grafik nilai tukar rupiah terhadap dolar AS sejak 2014:

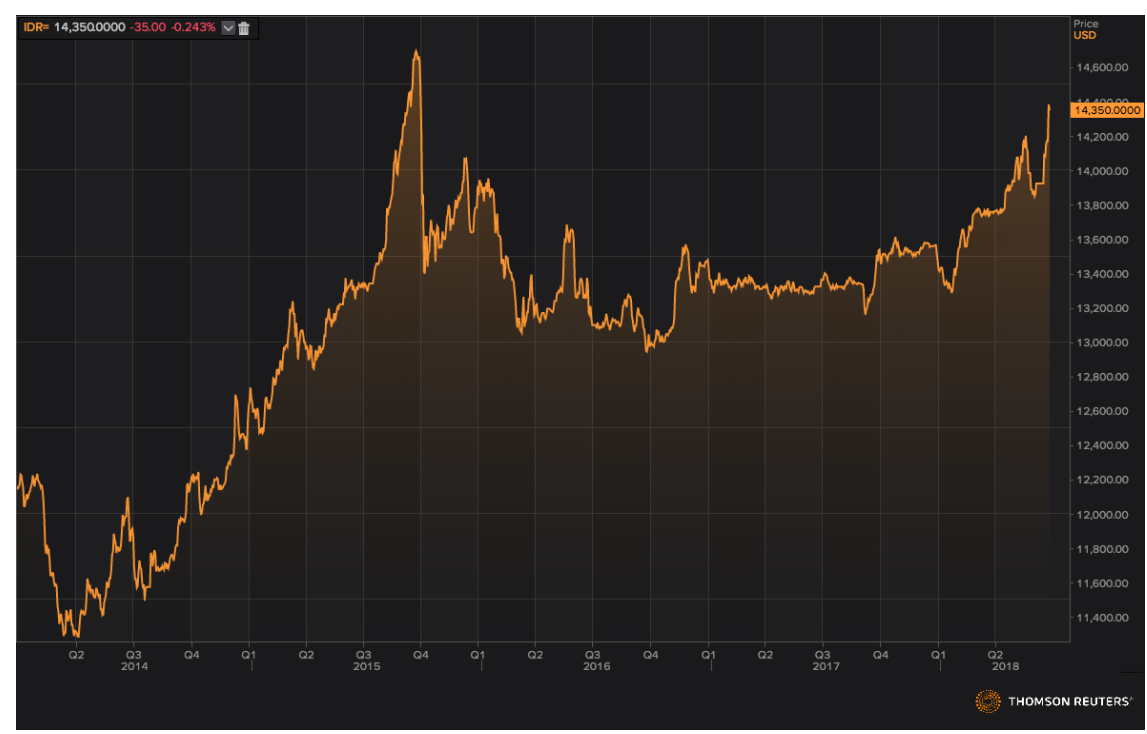

Gambar 2. Grafik kurs rupiah sejak 2014(CNCBC Indonesia)

Kurangnya lapangan pekerjaan menjadi faktor adanya pengangguran. Dengan memberi mereka peluang kerja dapat mengurangi banyaknya pengangguran. Mengajak pengangguran untuk bekerja sama membuat usaha kecil-kecilan itu juga membantu mengurangi pengangguran. Dengan hal itu mendapat keuntungan yang besar. Selain 
mendapat ilmu secara sedikit demi sedikit juga mendapat penghasilan sedikit demi sedikit pula.

SDM yang masih Rendah juga menjadi pemicu perekonomian di Indonesia. Faktor penyebab rendahnya SDM di Indonesia ini yaitu kurangnya pemerataan pendidikan. Pemerintah seharusnya bergerak di daerah-daerah terpencil dan memberikan fasilitas pendidikan yang layak. Agar mengurangi SDM yang sedang rendah. Selain itu, pemeritah harus memeriksa data mana saja masyarakat atau warga yang berhak mendapat pendidikan secara gratis. Dengan ini akan menjadi seimbang dan juga mereka yang kekurangan dalam segi ekonomi masih bisa merasakan manisnya pendidikan secara gratis.

\section{Sampah}

Sampah menggunung dimana-mana. Hampir disetiap tempat dan sudut terdapat sampah. Banyak sampah kering dan basah gabung menjadi satu. Disertai bau yang menyengat pula. Dimana ada keramaian orang disitulah hadir sampah-sampah.

Melihat sampah yang menggunung begitu banyaknya. Kita menilai sampah tidak ada nilainya, sampah hanyalah barang bekas dan lainlainnya. Namun jika kita lihat kembali dan berfikir untuk mengurangi tumpukan sampah tersebut lalu kita sulap menjadi rupiah, lantas apa salahnya kita untuk mencobanya. Langkah awal, kita pilah dan pilih terlebih dahulu sampah yang akan kita jadikan sebuah barang yang nantinya jika dijual akan mendapat keuntungan yang besar.

Setelah memilih dan memilah sampah, selanjutnya kita mengolah sampah dengan mendaur ulang menjadi sebuah barang yang baru. Seperti botol bekas disulap menjadi pot dimodif kartun anak, sedotan disulap menjadi bunga plastik, kaleng bekas disulap menjadi tempat pensil dan masih banyak lagi.

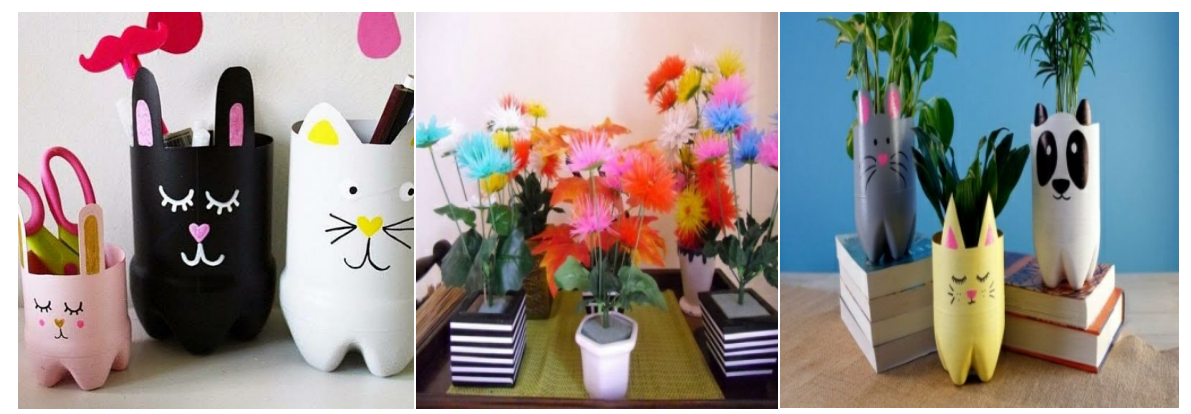

Gambar 3. Botol bekas jadi tempat pensil, Gambar 4. Sedotan jadi bunga plastik, Gambar 5. Botol bekas jadi pot bunga kartun anak.

Kita juga bisa mengajak keluarga, saudara, tetangga, dan teman-teman 
pengangguran yang ada disekitar kita untuk bersama-sama membuat usaha kecil yang berbahan dasar sampah. Dengan menggunakan kreativitas, kesabaran, dan keuletan bahan sampah yang sudah dipilah dan diolah tersebut bisa menjadi suatu hal yang menarik di masyarakat sekitar. Selain itu, kita memilih sampah sebagai bahan dasarnya kita sudah menyelamatkan bumi kita dari bencana alam dan menjaga bumi agar tetap lestari.

\section{Penutup}

Sampah adalah suatu barang atau bahan yang dihasilkan dari aktivitas makhluk hidup yang dibuang karena sudah tidak layak dipakai atau sudah tidak memiliki nilai. Sampah ada dua macam, yaitu sampah organik dan sampah anorganik. Sampah anorganik memang membutuhkan waktu yang sangat lama dalam penguraiannya. Namun jika kita mendaur ulang kembali sampah anorganik menjadi barang yang memiliki harga jual tinngi mengapa tidak mencobanya. Apabila kita menginginkan membuat usaha dan mengajak keluarga, saudara, tetangga, dan teman-teman pengangguran yang ada disekitar kita untuk dijadikan rekan kerja dan bisnis kita mendapatkan keuntungan yang banyak seperti menambah teman baru, memperoleh wawasan, dan dapat belajar bersama. dengan hal ini kita menolong bumi kita dari bencana alam.

\section{Daftar Pustaka}

Ashar, F. (2013, November 13). Pengertian Sampah dan Jenis Sampah. Retrieved December 29, 2018 ,from http://pengertianahli.id/2013/11/pengertian-sampah-dan-jenissampah.html

Purnomo, H. (2018, 29 Juni). Catat Rekor Terburuk, Seperti Ini Grafik Rupiah Dari 2014. Diperoleh 29 Desember 2018, dari https://www.cnbcindonesia.com/market/20180629113049-17-

21039/catat-rekor-terburuk-seperti-ini-grafik-rupiah- sejak-2014

Riadi, M. (2015, 07 Februari). Pengertian, Jenis dan Dampak Sampah. Diperoleh 29 Desember 2018, dari https://www.kajianpustaka.com/2015/02/pengertian-jenis-dandampak-sampah.html?m=1

Lavinia. (2016, 24 Februari). Kurangnya Kepedulian Masyarakat Dalam Menjaga Kebersihan Lingkungan. Diperoleh 29 Desember 2018, dari https://www.kompasiana.com/lavinia/56cdb465379773071ed7673b /kurangnya-kepedulian-masyarakat-dalam-menjaga-kebebananlingkungan

Miftahudin, H. (2016, 12 Mei). Rendahnya Kualitas SDM Pengaruhi Perubahan Industri Nasional. Diperoleh pada 29 Desember 2018, dari 
http://www.metrotvnews.com/amp/nbwd1M6k-rendahnya-kualitassdm-pengaruhi-pertumbuhan-industri-nasional. 